\title{
Contamination of Senior Medical Students' Cell Phones by Nosocomial Infections: A Survey in a University-Affiliated Hospital in
} Tehran

\author{
Sana Jalalmanesh, ${ }^{1}$ Mohammad Darvishi, ${ }^{2,}{ }^{,}$Mohammadkarim Rahimi, ${ }^{3}$ and Meisam Akhlaghdoust ${ }^{4,}$ \\ ${ }^{1}$ Medical Student at Tehran Medical Branch of Islamic Azad University, Tehran, IR Iran \\ ${ }^{2}$ Infectious Diseases and Tropical Medicine Research Center (IDTMRC), AJA University of Medical Sciences, Tehran, IR Iran \\ ${ }^{3}$ Department of Medicine, Tehran Medical Branch of Islamic Azad University, Tehran, IR Iran \\ ${ }^{4}$ Pars Advanced and Minimally Invasive Manners Research Center, Pars Hospital, Iran University of Medical Sciences, Tehran, IR Iran
}

"Corresponding authors: Mohammad Darvishi, Infectious Diseases and Tropical Medicine Research Center (IDTMRC), AJA University of Medical Sciences, Tehran, IR Iran. E-mail: mo_darvishi@yahoo.com; Meisam Akhlaghdoust, Pars Advanced and Minimally Invasive Manners Research Center, Pars Hospital, Iran University of Medical Sciences, Tehran, IR Iran. E-mail: meisam_akhlagh@yahoo.com

Received 2016 November 13; Revised 2017 February 28; Accepted 2017 March 05.

\section{Abstract}

Background and Purpose: Nosocomial infections are a growing problem in many health centers. Cell phones used by the medical staff can act as a vector for nosocomial transmission of microorganisms. This study aimed to investigate the role of cell phones of senior medical students in the spread of nosocomial bacterial infections in Amir-al-Momenin general hospital in Tehran in September 2015.

Methods: Thirty medical students were enrolled using convenience sampling method. Demographic data, perspectives, attitudes, phone type, and frequency of cleaning of mobile phones were collected by questionnaires. Samples were taken from the phones using a sterile swab moistened with a nutritive medium in order to assess the possibility of bacterial growth.

Results: A total of 53.3 percent of mobile phones were infected. Isolated bacteria were: Staphylococcus epidermidis (26.7\%), Nonalbicans Candida (16.7\%), Bacillus PSP (13.3\%), Micrococcus PSP (10\%), non-hemolytic Streptococcus and Enterococcus (each 6.7\%), and Klebsiella and Staphylococcus aureus (each 3.3\%).

Conclusions: Mobile phones can act as potential carriers of nosocomial infections which are significantly higher in male students' phones and in smartphones. So, some restrictions should be applied to their use in sensitive areas of hospitals. Also, due to the significant impact of cleaning mobile phones in reducing the frequency of bacterial contamination, attention to their regular cleaning should be considered.

Keywords: Cell Phone, Medical Students, Nosocomial Bacterial Infections

\section{Introduction}

Nosocomial infections are growing increasingly and causing high mortality; as such, they affect $25 \%$ of hospitalized patients in the developing countries (1). Annually, 1.7 million patients suffer from nosocomial infections in the United States, 100,000 of which die (2). Pathogen agents of nosocomial infections may spread through the hands of hospital personnel, thermometers, stethoscopes, and even children's toys in intensive care units in the hospitals (1).

In 1982, the global will for using cell phones to communicate more easily first started in Europe. Now, cell phones are essential devices for social and personal life. Although they are usually kept in bags or pockets, they are in close contact with people's hands and face (3). Currently, cell phones are used in any place. These places may include dinner tables, kitchens, restaurants, gyms, and even bathrooms and WCs. These factors and the heat produced by cell phones let bacteria grow on the surface of these de- vices (2).

Cell phones are usually used in hospital corridors, laboratories, or intensive care units which is dedicated to taking care of patients with severe diseases (1). Extensive use of cell phones among medical personnel in hospitals is kind of a contrast. The question is how to use cell phones while reducing its disadvantages. For example, surgeons can consult their colleagues and masters in urgencies or seek help form technical personnel if some devices broke during the operation. On the other hand, cell phone of the surgeons may cause wound infection (4).

In Ulger et al.'s study in 2009, 94.5\% of cell phones were affected with different bacteria, $31.3 \%$ of which were gram negative bacteria and $39.5 \%$ of the bacteria of users' hands were resistant to cephtazidim. A total of 52\% of phones were infected with Staphylococcus aurous and 37.7\% of users' hands were methicillin resistant (MRSA). Studies have shown that the bacteria isolated form users' hands 
and cell phones are the same (4). In another study which was conducted by Ebrahim Badr et al. in 2012, it is shown that the contamination of hospital personnel's hands has increased by $93.7 \%$ after using cell phones (3). In Bhat et al.'s study in 2012, second culture, after cell phones were cleaned by an alcohol pad, they showed no bacterial growth (2).

Due to the importance of the hospital personnel and medical students' awareness of pathogen agents and the importance of hygiene as well as the lack of studies about the potential role of cell phones in spreading infections in the country, current study was conducted to determine the role of medical students' cell phones in spreading bacterial infections in Amir-al-Momenin Hospital in September 2015.

\section{Methods}

The current study is a descriptive analytical study performed with cross sectional method in 2015 . Study society included senior medical students of Amir-al-Momenin general hospital affiliated with Islamic Azad University of Medical Sciences in Tehran in September 2015. Data samplings were calculated from the infectious ward. According to the formula of the calculation of sample size in descriptive studies giving 0.05 type I error, the 0.95 probability of cell phones' bacterial contamination (based on Akinyemi et al.'s (2009) study (3)), and the study accuracy of $10 \%$ of bacterial contamination of cell phones, at least 20 people had to be included in this study. To achieve higher accuracy, 30 participants were included.

Demographic information including age and gender, viewpoint, attitude, type of cell phone, and the frequency of cleaning the cell phone was collected via a questionnaire. Then, using sterile swabs, the sample was taken from the surface of the students' cell phones. In addition, after cleaning the phone with alcohol cotton, another sample was taken. Sterile swabs, tubes containing broth culture media, plates of blood agar culture media, and Macconkey agar culture media were used. Sterile swab was floated in a tube containing liquid media, extracted and contacted with a certain area in the surface of cell phones $\left(5 \mathrm{~cm}^{2}\right)$, and then put into broth media. Then, tubes were transferred to the laboratory and incubated at 37 degrees centigrade in the incubator for 24 hours. Using a swab or aans, inoculation was performed on the surface of solid media (blood agar or Macconkey agar). After 24 hours, the number of colonies at the surface of the culture media, wheatear being gram positive or gram negative, was calculated and the differentiation of genus and species was done. Obviously, the control tests of culture media and sampling of surface after disinfecting were performed.
Lab's protocol in this study was performed based on clinical and laboratory standards institute performance standards for antimicrobial susceptibility testing: twentieth informational supplement in 2010 (5).

To determine the relation between qualitative variant, chai-square test, and accurate fisher test and to compare the averages between the two groups, T-test was used. In all cases, the significance level was set to be 0.05 .

\section{Results}

The results of this study are summarized in Table 1. Mean age of participants was , $56.7 \%$ and $43.3 \%$ of them were male and female, respectively. A total of $70 \%$ of students had smartphones and 30\% of them had non-smart cell phones. All students were aware that microbial agents might spread by cell phones and that this risk could be prevented by cleaning the cell phones. A total of $50 \%$ of students cleaned their cell phones more than once a day, $36.7 \%$ just once a day, and $13.3 \%$ of them did not clean their cell phones. It was shown that female students cleaned their cell phones significantly more often than male students ( $P$ $=0.026$ ).

Table 1. Characteristics of Cell Phones, User and Microbial Contamination

\begin{tabular}{l|c|c}
\hline \multirow{2}{*}{ Phone Type } & Variant & No. (\%) \\
\hline \multirow{2}{*}{ Status of awareness } & Smart & $21(70)$ \\
\cline { 2 - 3 } & Non-smart & $9(30)$ \\
\hline \multirow{2}{*}{ Status of attitude } & Aware & $30(100)$ \\
\cline { 2 - 3 } & Not aware & 0 \\
\hline \multirow{2}{*}{ Cell phone cleaning frequency (Per day) } & Proper & $30(100)$ \\
\cline { 2 - 3 } & Improper & 0 \\
\cline { 2 - 3 } & Never & $4(13.3)$ \\
\cline { 2 - 3 } & Once & $11(36.7)$ \\
\cline { 2 - 3 } & Twice & $12(40)$ \\
\cline { 2 - 3 } & Three times & $3(10)$ \\
\hline
\end{tabular}

Microbial contamination prevalence of cell phones of students was $53.3 \%$ before cleaning and only $46.67 \%$ after cleaning which showed a significant difference $(\mathrm{P}<0.001)$ (Figure 1). The prevalence of microbial contamination in the cell phones of male students was significantly higher compared to female students (70.6\% and 30.8\% respectively, $\mathrm{P}=0.030$ ). Moreover, the prevalence of microbial contamination in smartphones was significantly higher compared to non-smart cell phones (66.7\% and $22.2 \%$ respectively, $\mathrm{P}=0.046$ ). 


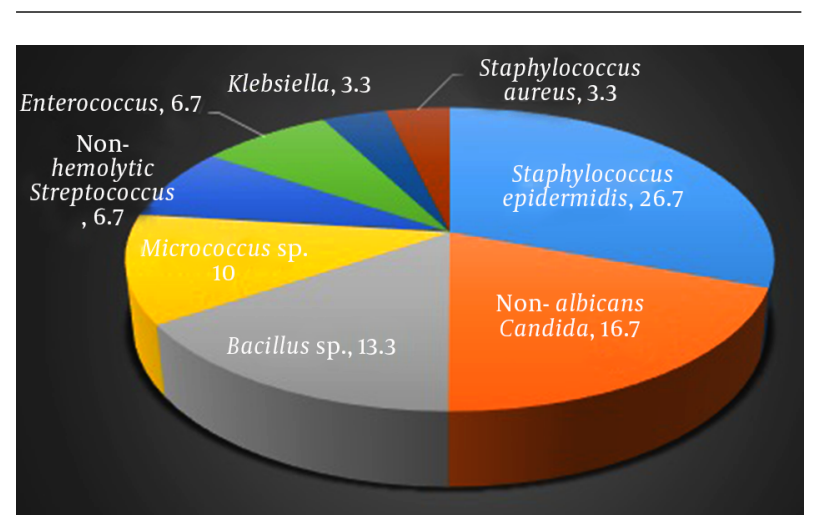

Figure 1. The Prevalence of Microbial Contamination of Cell Phones of Senior Medical Students in a General Hospital Affiliated with Tehran University of Medical Sciences

Collectively, 8 types of bacteria were isolated from samples of 30 cell phones before cleaning which are in accordance with frequency as follows: Staphylococcus epidermidis in 8 cases (26.7\%), non-albicans Candida in 5 cases (16.7\%), Bacillus sp. in 4 cases (13.3\%), Micrococcus sp. in 3 cases (10\%), non-hemolytic Streptococcus and Enterococcus each in 2 cases (each 6.7\%), and indeed Klebsiella and Staphylococcus aureus each in 1 case (each 3.3\%), (Figure 2). It is of note that in samples after cleaning the cell phones, only 2 cases of positive culture were recorded, including: Staphylococcus epidermidis and Micrococcus sp. each in one case. Both of these cell phones had been contaminated with the same microorganism prior to cleaning (Table 2).

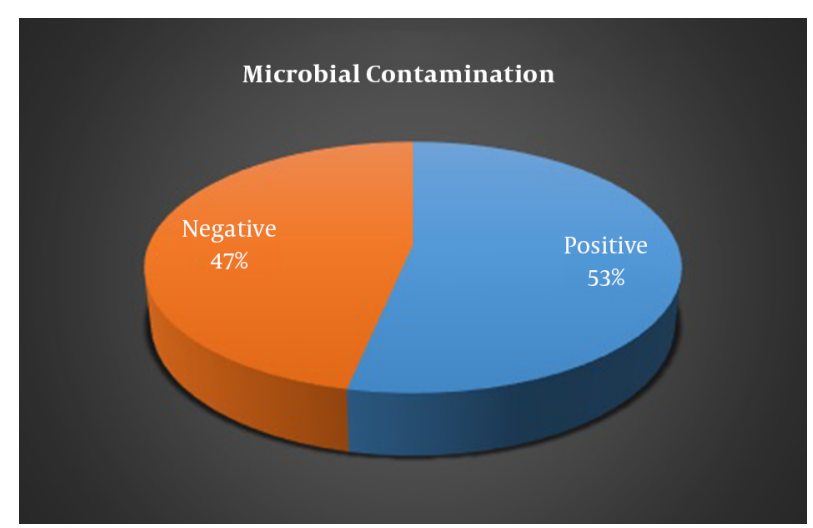

Figure 2. Microbial contamination of Cell Phones of Senior Medical Students in a General Hospital Affiliated with Tehran University of Medical Sciences

\section{Discussion}

Nosocomial infections are a growing concern in health care centers (5-7). Hand, devices, cell phones, or other
Table 2. Results of T-Test

\begin{tabular}{|c|c|c|c|}
\hline & Variant & No. (\%) & P Value \\
\hline \multirow{2}{*}{$\begin{array}{l}\text { Rate of Phone } \\
\text { Cleaning }\end{array}$} & Male & $17(56.7)$ & \multirow{2}{*}{0.026} \\
\hline & Female & $13(43.3)$ & \\
\hline \multirow{4}{*}{$\begin{array}{l}\text { Microbial con- } \\
\text { tamination }\end{array}$} & Positive & $16(53.3)$ & \multirow{2}{*}{$<0.001$} \\
\hline & Negative & $14(46.7)$ & \\
\hline & Male, \% & 70.6 & \multirow{2}{*}{0.030} \\
\hline & Female, \% & 30.8 & \\
\hline & Smart Phone & & \multirow{2}{*}{0.046} \\
\hline & $\begin{array}{l}\text { Non Smart } \\
\text { Phone }\end{array}$ & & \\
\hline \multirow{8}{*}{$\begin{array}{l}\text { Isolated mi- } \\
\text { croorganisms }\end{array}$} & $\begin{array}{l}\text { Staphylococcus } \\
\text { epidermidis }\end{array}$ & $8(26.7)$ & \multirow{8}{*}{0.026} \\
\hline & $\begin{array}{l}\text { Non-albicans } \\
\text { candida }\end{array}$ & $5(16.7)$ & \\
\hline & Bacillus sp. & $4(13.3)$ & \\
\hline & Micrococcus sp. & $3(10)$ & \\
\hline & $\begin{array}{l}\text { Non-hemolytic } \\
\text { streptococcus }\end{array}$ & $2(6.7)$ & \\
\hline & Enterococcus & $2(6.7)$ & \\
\hline & Klebsiella & $1(3.3)$ & \\
\hline & $\begin{array}{c}\text { Staphylococcus } \\
\text { aureus }\end{array}$ & $1(3.3)$ & \\
\hline
\end{tabular}

nonliving things used by medical staff can act as vectors to spread microorganisms (8-11). Contrary to landline phones, cell phones being used in these centers, are used in close contact with patients who are susceptible to the infections $(4,12)$. This study was conducted to evaluate the role of medical students' cell phones on bacterial infection spread in Amir-al-Moumenin hospital in September 2015.

Sepehri et al. studied on 150 randomly selected health care worker's in 3 teaching hospitals in 2007, too. According to the study that was performed in Kerman, Iran, 48 cell phones and 59 of dominant hands demonstrated bacterial contamination and Staphylococcus epidermidis. So, cell phones might be a significant source of nosocomial infections (13). In this study, 30 cell phones of 30 medical students were evaluated to investigate bacterial infections. Results showed 53.3\% (16 cases) of microbial contamination.

Studies conducted around the world show the prevalence of microbial contamination in cell phones of medical staff. Karabay et al.'s (1) study in Turkey showed that 91\% of cell phones of medical staff were contaminated with bacterial agents. In Bhat et al.'s (2) study in India, 99\% of cell phones were contaminated with bacteria. In Akineyemi et al.'s (3) study in Nigeria, 30.6\% of cell phones 
of medical staff were contaminated with bacterial agent. In Elkholy et al.'s (4) study in Egypt, 96.5\% of samples showed positive cultures. Another study in Turkey conducted by Ulger et al. (14) showed that $94.5 \%$ of cell phones of the operation room and ICU personnel were contaminated with various bacteria. In the study conducted by Tagoe et al. (15) in Ghana, $47 \%$ of cell phones of medical students were contaminated with bacteria. In Sepehri et al.'s (13) study in Kerman, 32\% percent of cell phones of medical staff were contaminated with bacterial agents. Results of Sridhar et al. (16) in India indicates 70\% of contamination of the cell phones of health workers. Srikanth et al. (17) in Singapore showed that $71 \%$ of cell phones of health workers resulted in positive microbial growth.

As discussed above, some studies reported higher prevalence of microbial contamination and some showed lower prevalence compared to the reported prevalence in this study. This may be due to different attitudes towards infection spread via cell phones and the diversity of cleaning and disinfecting plans in different countries and different health care centers.

Collectively, 8 types of bacteria were isolated from 30 cell phones, the most prevalent of which was Staphylococcus epidermidis which was observed in $26.7 \%$ of samples ( 8 cell phones).

Staphylococcus epidermidis is the most important member of coagulase negative staphylococcus and part of human normal microbial flora located in nasal mucus and higher respiratory tract (18). This bacteria was long considered saprophyte due to its ubiquitous nature and relatively low pathogenicity. However, in recent decades, as an implantable medical device, such as catheters and prostheses, it emerged as an important nosocomial pathogen (19). While no colonies of Staphylococcus epidermidis have been observed on cell phones, cell phones can transfer these pathogens by contacting with other plastic surfaces such as catheters or prostheses, and by this way they let them in the body (20). Generally, Staphylococcus sp. are becoming prevalent and statistical analysis in most countries has shown that staphylococcus epidermidis is the most prevalent cause of sepsis and of common causes of urinary tract infections $(18,21)$.

The next microorganism isolated form the cell phones of medical students according to prevalence, was nonalbicans Candida contamination which was observed in 5 cell phones (16.7\%).

Candida sp. are ubiquitous organisms and opportunist infectious agents in patients with immunodeficiency. The increase in the prevalence of fungal infections in patients with immunodeficiency has been prevalent (22-24) and it has attracted higher attentions in recent decades $(25,26)$. Although, Candida albicans, as the most prevalent cause of candidiasis, is of great importance, recent epidemiologic studies have shown that non-albicans Candida are replacing Candida albicans $(22,23,27-30)$ as it is observed that the prevalence of candidemia has increased by $500 \%$ from 1980 s (25) and more than $1.3 \%$ of all infections are caused by non-albicans Candida sp.. Previous studies have shown that candida may be isolated from 15 to $54 \%$ of health workers (25). Thus, there is the risk of candida infection from exogenous source for patients at risk.

The third prevalent microorganism isolated from medical students' cell phones, was bacillus sp. which was observed in 4 cell phones (13.3\%).

Bacillus bacteria are Gram-positive, sporulated, and rrod-shaped. Their impact on human ranges from being probiotic (31) to being severely pathogen. Many species of this genus are associated with diseases related to food products that can be severe or even lethal. Due to forming spores, these bacteria are resistant to disinfectant agents and may stay alive even after disinfection (32). Consequently, there is always a major concern about the contamination of foodstuff and hospital devices with species of this bacteria (33-36) that cell phones can play a role as a vector. Based on previous studies conducted in Iran, the prevalence of bacillus species on hands of personnel and hospital surfaces were $60 \%$ and $26.3 \%$, respectively $(32,37)$.

In this study, micrococcus sp. were the fourth prevalent isolated organism from cell phones of medical students (10\%). These bacteria are located in various places such as water, soil and are part of normal skin microbial flora, frequently found on devices which are not adequately cleaned or disinfected (38). Generally, micrococcus sp. are considered on-haring bacteria and up to authors' knowledge, have not been reported as nosocomial infection agents. Though, rare cases of micrococcus infections in patients with immunodeficiency, such as AIDS patients, have been reported.

Non-hemolytic Streptococcus and Enterococcus, each have been isolated form 2 cell phones of medical students (each 6.7\%).

Non-hemolytic Streptococcus are part of normal skin microbial flora and of the most common bacteria found in upper respiratory tract and conjunctiva which rarely cause diseases in humans (39). Though, these bacteria have been isolated from patients with pharyngitis $(40,41)$, pneumonia (42), sepsis $(43,44)$, and cellulitis (45).

Enterococcus sp. are facultative anaerobic grampositive cocci observed couple or in short chains (46). These bacteria are also part of female reproductive tract and gastrointestinal tract (47). Two symbiotic species of enterococci are Enterococcus faecalis (90\% - 95\%) and Enterococcus faecium (5\% - 10\%) (48). Enterococci are the second cause of nosocomial infections around the world and the 
main cause in the United States accounting for 20 to $30 \%$ of infections (49). Generally, main infections caused by enterococci include urinary tract infections, bacteremia, endocarditis, and meningitis (48).

The least prevalent microorganisms isolated in this study were Klebsiella and Staphylococcus aureus each in 1 case (each 3.3\%).

Klebsiella sp. especially Klebsiella pneumonie are important members of entrobacteriacea and are opportunist pathogens associated with nosocomial acquired infections such as neonatal infections, septicemia, pneumonia , urinary tract infection, and wound infections (50). Generally, 3 to $7 \%$ of bacterial nosocomial infections are associated with Klebsiella pneumonie which is the eighth major pathogen in healthcare centers whose endangering prevalence is increasing $(51,52)$.

Among several Staphylococci sp., Staphylococcus aureus is one of the most important pathogen agents and one of the most common causes of nosocomial infections (53). These bacteria, Gram-positive cocci, catalase and coagulase positive, fixed and facultative anaerobic and do not form spore (54). Staphylococcus aureus is usually found in human's skin and respiratory tract and is the cause of various infections including pneumonia and bacteremia (55). Methicillin resistant Staphylococcus aureus, due to resistance to beta-lactam antibiotics are of great importance in medical society. Nevertheless, it has been shown that the probability of their presence on cell phone surfaces is highly low (56).

Generally, in studies performed all over the world, different bacteria have been isolated from cell phones of medical staff in health care centers which are diverse both in accordance with isolated bacteria and their prevalence. These differences can be attributed to different causes including difference in sampling society, number of samples, group of people who have been sampled, and possible errors in sampling and testing. Results of these studies are reviewed briefly.

Isolated pathogens from medical personnel (doctor, nurse, resident, and intern) in Karabay et al.'s (1) study included Escherichia coli (40\%), Enterococcus fecalis (20\%), Pseudomonas aeruginosa (20\%), Pseudomonas fluorescens (10\%), and Klebsiella pneumonie (10\%). Isolated bacteria from cell phones of doctors and dentists in Baht et al.'s (2) study included Staphylococcus aureus, Escherichia coli, Klebsiella pneumonie, Acinetobacter, Enterococcus fecalis, and Pseudomonas aeruginosa. The most prevalent isolated bacteria from health staff and workers in Akinyemi et al.'s (3) study included Staphylococcus aureus (36.8\%), coagulase negative Staphylococcus (26.3\%), Enterococcus fecalis and Pseudomonas aeruginosa (each 10.5\%), and Escherichia coli, Klebsiella pneumonie, and Bacillus sp. (each 5.3\%). Isolated bacteria from cell phones of ICU staff in Elkholy et al.'s (4) included 33\% Staphylococcus, 20\% Gram-negative bacteria, 24\% coliform, 11\% Enterococcus, and 12\% yeast. In Ulger et al.'s (14) study, 31.3\% of cell phones of the operation room and ICU staff, contained Staphylococcus aureus. In Tagoe et al.'s (15) study, isolated bacteria form cell phones of medical students included $23 \%$ of Bacillus cereous, $19 \%$ of Proteus mirabilis, $3 \%$ of Salmonella, and $2 \%$ of Shigella. The most common isolated pathogen from health care centers staff in Sepehri et al.'s (13) study was Staphylococcus epidermidis (32\% of cell phones). In Sridhar et al.'s (16) study, $46 \%$ of cell phones of health care staff were contaminated with micrococci, $8 \%$ with coagulase negative streptococcus, $5 \%$ with Staphylococcus aureus, $1 \%$ with Pseudomonas stutzeri, $2 \%$ with Acinetobacter baumannii, $1 \%$ with Citrobacter freundii, $3 \%$ with Klebsiella oxytoca, $2 \%$ with non-albicans Candida, $1 \%$ with trichosporon, and $1 \%$ with Aspergillus niger. Pathogen bacteria of cell phones of health staff in the study conducted by Srikanth et al.'s (17) included Staphylococcus aureus, Escherichia coli, Klebsiella pneumonie, and Pseudomonas aeruginosa.

According to the answered questionnaire by the participants, all the studied society were aware that cell phones might be microbial vectors especially for nosocomial bacteria and indicated that cleaning cell phones could be helpful in reducing this risk. Nevertheless, $13.3 \%$ of participants did not clean their phone any time a day at all. This rate is lower compared to previously reported rates. In Ali Ghardashi et al.'s (57) study, it was proved that almost 94\% of medical staff (doctors, medical students, nurses, paramedics) were aware that cell phones might be microbial vectors especially for nosocomial bacteria. However, $44 \%$ percent of them never cleaned their cell phones. In Morioka et al.'s (58) study, despite the awareness of nurses to wash their hands after routine procedures, 33.6\% of them did not wash their hands after using cell phones. In Zakai et al.'s (59) study, 67.6\% of medical students indicated that they did not clean their cell phones even once a day. Some other studies have shown that nearly 80 to $92 \%$ of health care personnel do not clean their cell phones at all $(8,60,61)$.

Moreover, results of the current study showed that cleaning cell phones results in a significant decrease in microbial contamination on the surfaces of cell phones, as such microbial contamination was significantly less frequent after cleaning the cell phones $(\mathrm{P}<0.001)$. These findings were consistent with previous studies; it has been shown that a suitable method to disinfect cell phones is cleaning them with alcohol 70\% which results in less contamination (9, 60-65).

Another result of this study was that there were statistically meaningful relations between gender and microbial 
contamination of cell phones ( $\mathrm{P}=0.030$ ) as such, microbial contamination prevalence was significantly lower in female students compared to male students. In previous studies performed by Barari et al. (66), the prevalence of microbial contamination was lower in females, but the difference was not significant $(P=0.089)$. It may be due to the serious attention of ladies to cleanness which is true for their cell phones as well.

Moreover, findings of this study showed that there is a statistically meaningful relation between type of cell phones (smart or non-smart) on the level of microbial contamination $(\mathrm{P}=0.046)$. Microbial contamination of smart phones were significantly higher compared to non-smart cell phones. To our knowledge, this comparison has not been performed before. Perhaps the most important reason may be that smart cell phones provide much higher software and hardware possibilities which result in being more frequently used for longer periods of time which indeed results in higher spread of microbial agents.

Since cell phones of students are contaminated to pathogen microorganisms, concerns of transmission of contamination via cell phones especially in sensitive sections such as operation room, ICU and burning ward have increased $(9,67)$. Thus, an important part of the safety of patients (esp. patients at risk) is dedicated to lowering the potential of contamination transmission via cell phones (68). Consequently, it is suggested that medical students be informed about possible ways of the transmission of nosocomial infections and how to prevent them before starting clinical practice in hospitals. Since, microbial contamination is more prevalent in the male's cell phones, this instruction should be more emphasized on for male students.

Since $13.3 \%$ of medical students indicated that they did not clean their cell phones, and due to the presence of these students in different wards of the hospital, their cell phones might act as microbial vector. In this regard, it is suggested that instruction and visual reminders (brochures and posters) for attracting attention to the cleaning of cell phones, limitation of cell phone usage in sensitive sections, and keeping them clean be used in hospitals; especially, since results have shown that cleaning the cell phones reduces their contamination.

To prove the direct relationship between cell phone usage in hospitals with nosocomial infections and infection transmission requires further evaluations. In this regard, different pathogens' capability to survive on the surface of cell phones, survival time, and the risk of pathogen transmission to patients should be further studied.

\section{References}

1. Karabay O, Koçoglu E, Tahtaci M. The role of mobile phones in the spread of bacteria associated with nosocomial infections. J Infect Dev Ctries. 2007;1(1):72-3.

2. Bhat SS, Hegde SK, Salian S. Potential of mobile phones to serve as a reservoir in spread of nosocomial pathogens. Online J Health Allied Sci. 2011;10(2).

3. Akinyemi KO, Atapu AD, Adetona OO, Coker AO. The potential role of mobile phones in the spread of bacterial infections.J Infect Dev Ctries. 2009;3(8):628-32. [PubMed: 19801807].

4. Elkholy MT, Ewees IE. Mobile (cellular) phone contamination with nosocomial pathogens in Intensive care units. Med J Cairo Univ. 2010;78(2):1-5.

5. Clinical and Laboratory Standards Institute . Performance standards for antimicrobial susceptibility testing: twentieth informational supplement, M100-S20. ;2010. pp. 1-188.

6. Kennedy KJ, Dreimanis DE, Beckingham WD, Bowden FJ. Staphylococcus aureus and stethoscopes. Med J Aust. 2003;178(9):468. [PubMed: 12720501].

7. NNIS . National Nosocomial Infections Surveillance (NNIS) system report, data summary from January 1992-April 2000, issued June 2000. Am J Infect Control. 2000;28(6):429-48. [PubMed: 11114613].

8. Brady RR, Wasson A, Stirling I, McAllister C, Damani NN. Is your phone bugged? The incidence of bacteria known to cause nosocomial infection on healthcare workers' mobile phones. $J$ Hosp Infect. 2006;62(1):123-5. doi: 10.1016/j.jhin.2005.05.005. [PubMed: 16099536].

9. Brady RR, Fraser SF, Dunlop MG, Paterson-Brown S, Gibb AP. Bacterial contamination of mobile communication devices in the operative environment. J Hosp Infect. 2007;66(4):397-8. doi: 10.1016/j.jhin.2007.04.015. [PubMed: 17573157].

10. Singh S, Acharya S, Bhat M, Rao SK, Pentapati KC. Mobile phone hygiene: potential risks posed by use in the clinics of an Indian dental school.J Dent Educ. 2010;74(10):1153-8. [PubMed: 20930247].

11. Schultz M, Gill J, Zubairi S, Huber R, Gordin F. Bacterial contamination of computer keyboards in a teaching hospital. Infect Control Hosp Epidemiol. 2003;24(4):302-3. doi: 10.1086/502200. [PubMed: 12725363].

12. Jeske HC, Tiefenthaler W, Hohlrieder M, Hinterberger G, Benzer A Bacterial contamination of anaesthetists' hands by personal mobile phone and fixed phone use in the operating theatre. Anaesthesia. 2007;62(9):904-6. doi: 10.1111/j.1365-2044.2007.05172.x. [PubMed: 17697216].

13. Sepehri G, Talebizadeh N, Mirzazadeh A, Mir-shekari TR, Sepehri E. Bacterial Contamination and Resistance to Commonly Used Antimicrobials of Healthcare Workers' Mobile Phones in Teaching Hospitals, Kerman, Iran. Am J Appl Sci. 2009;6(5):806-10. doi: 10.3844/ajassp.2009.806.810.

14. Ulger F, Esen S, Dilek A, Yanik K, Gunaydin M, Leblebicioglu H. Are we aware how contaminated our mobile phones with nosocomial pathogens?. Ann Clin Microbiol Antimicrob. 2009;8:7. doi: 10.1186/14760711-8-7. [PubMed: 19267892].

15. Tagoe DN, Gyande VK, Ansah EO. Bacterial contamination of mobile phones: When your mobile phone could transmit more than just a call. Webmedcentral Microbiol. 2011;2(10).

16. Sridhar G, Keerthana A, Karthika J, Raja D, Jasmine Priscilla D. Bacterial and fungal colonization of mobile phones used by health care workers-an emerging threat. Health Care. 2013;1(2):3-4.

17. Srikanth P, Ezhil R, Suchitra S, Anandhi I, Maheswari U, Kalyani J. The Mobile Phone in a Tropical Setting-Emerging Threat for Infection Control. Int J Infect Dis. 2008;12:e367. doi: 10.1016/j.ijid.2008.05.973.

18. Jawetz E, Melnick GL, Adelberg EA. Review of medical microbiology. Mc Graw Hill Inc; 1964.

19. Mathur T, Singhal S, Khan S, Upadhyay DJ, Fatma T, Rattan A. Detection of biofilm formation among the clinical isolates of Staphylococci: an evaluation of three different screening methods. Indian J Med Microbiol. 2006;24(1):25-9. [PubMed:16505551]. 
20. Otto M. Staphylococcus epidermidis-the 'accidental' pathogen. Nat Rev Microbiol. 2009;7(8):555-67. doi: 10.1038/nrmicro2182. [PubMed: 19609257].

21. Marshall SA, Wilke WW, Pfaller MA, Jones RN. Staphylococcus aureus and coagulase-negative staphylococci from blood stream infections: frequency of occurrence, antimicrobial susceptibility, and molecular (mecA) characterization of oxacillin resistance in the SCOPE program. Diagn Microbiol Infect Dis. 1998;30(3):205-14. [PubMed: 9572028].

22. Fidel PJ, Vazquez JA, Sobel JD. Candida glabrata: review of epidemiology, pathogenesis, and clinical disease with comparison to C. albicans. Clin Microbiol Rev. 1999;12(1):80-96. [PubMed: 9880475].

23. Odds FC. Ecology and Epidemiology of Candidiasis. In: Odds FC, editor. Candida and Candidosis. University Park Press Baltimore; 1998. p. 89.

24. Beck-Sague C, Jarvis WR. Secular trends in the epidemiology of nosocomial fungal infections in the United States, 1980-1990. National Nosocomial Infections Surveillance System. J Infect Dis. 1993;167(5):1247-51. [PubMed: 8486965].

25. Pfaller MA. Epidemiology of candidiasis. J Hosp Infect. 1995;30:329-38.

26. Gauzit R, Cohen Y, Dupont H, Hennequin C, Montravers P, Timsit JF, et al. [Infections by Candida sp. in intensive care. Survey of French practices]. Presse Med. 2003;32(10):440-9. [PubMed: 12733304].

27. Carrasco L, Ramos M, Galisteo R, Pisa D, Fresno M, Gonzalez ME. Isolation of Candida famata from a patient with acute zonal occult outer retinopathy. J Clin Microbiol. 2005;43(2):635-40. doi: 10.1128/JCM.43.2.635-640.2005. [PubMed: 15695657].

28. Pfaller MA, Jones RN, Doern GV, Fluit AC, Verhoef J, Sader HS, et al. International surveillance of blood stream infections due to Candida species in the European SENTRY Program: species distribution and antifungal susceptibility including the investigational triazole and echinocandin agents. SENTRY Participant Group (Europe). Diagn Microbiol Infect Dis. 1999;35(1):19-25. [PubMed: 10529877].

29. Krcmery V, Barnes AJ. Non-albicans Candida spp. causing fungaemia: pathogenicity and antifungal resistance. J Hosp Infect. 2002;50(4):243-60. doi: 10.1053/jhin.2001.1151. [PubMed:12014897].

30. Merz WG, Karp JE, Schron D, Saral R. Increased incidence of fungemia caused by Candida krusei. J Clin Microbiol. 1986;24(4):581-4. [PubMed 3771746].

31. Cutting SM. Bacillus probiotics. Food Microbiol. 2011;28(2):214-20. doi: 10.1016/j.fm.2010.03.007. [PubMed: 21315976].

32. Jalalpoor S, Kasra Kermanshahi R, Noohi AS, Zarkesh Esfahani H. Role and Important Staff Hands and Low and High Contact Hospital Surfaces to Produce and Controlling Nosocomial Infections. Iran J Med Microbiol. 2012;5(4):14-22.

33. Dohmae S, Okubo T, Higuchi W, Takano T, Isobe H, Baranovich T, et al. Bacillus cereus nosocomial infection from reused towels in Japan. J Hosp Infect. 2008;69(4):361-7. doi: 10.1016/j.jhin.2008.04.014. [PubMed: 18602188].

34. Bottone EJ. Bacillus cereus, a volatile human pathogen. Clin Microbiol Rev. 2010;23(2):382-98. doi: 10.1128/CMR.00073-09. [PubMed: 20375358].

35. Sasahara T, Hayashi S, Morisawa Y, Sakihama T, Yoshimura A, Hirai Y. Bacillus cereus bacteremia outbreak due to contaminated hospital linens. Eur J Clin Microbiol Infect Dis. 2011;30(2):219-26. doi: 10.1007/s10096-010-1072-2. [PubMed: 20938704].

36. Didelot X, Barker M, Falush D, Priest FG. Evolution of pathogenicity in the Bacillus cereus group. Syst Appl Microbiol. 2009;32(2):81-90. doi: 10.1016/j.syapm.2009.01.001. [PubMed: 19200684]

37. Jalalpour S, Kermanshahi RK, Nouhi AS, Esfahani HZ. Surveying the frequency of $\beta$-lactamase enzyme and antibiotic sensitivity pattern in isolated pathogen bacteria from low and high hospital contact surfaces. Pejouhandeh. 2010;15(2).

38. Aly R, Maibach HI. Aerobic microbial flora of intertrigenous skin. Appl Environ Microbiol. 1977;33(1):97-100. [PubMed: 836026].

39. Yoshino M, Murayama SY, Sunaoshi K, Wajima T, Takahashi M, Masaki
J, et al. Nonhemolytic Streptococcus pyogenes isolates that lack large regions of the sag operon mediating streptolysin $S$ production. $J$ Clin Microbiol. 2010;48(2):635-8. doi: 10.1128/JCM.01362-09. [PubMed: 20018818].

40. James L, McFarland RB. An epidemic of pharyngitis due to a nonhemolytic group A streptococcus at lowry air force base. $N$ Engl J Med. 1971;284(14):750-2. doi: 10.1056/NEJM197104082841403. [PubMed: 4994046].

41. Rubin LG, Mirkin GS. Apparent false positive detection of group a Streptococcus antigen resulting from pharyngeal infection with a nonhemolytic Streptococcus pyogenes. Pediatr Infect Dis J. 2000;19(7):672-4. [PubMed:10917236].

42. Taylor MB, Barkham $\mathrm{T}$. Fatal case of pneumonia caused by a nonhemolytic strain of Streptococcus pyogenes. J Clin Microbiol. 2002;40(6):2311-2. [PubMed: 12037120].

43. Cimolai N, Trombley C, Bhanju NM. Nonhemolytic Streptococcus pyogenes causing invasive infection. Clin Pediatr (Phila). 2002;41(6):453. doi: 10.1177/000992280204100616. [PubMed:12166801].

44. Turner DP, Gunn SL. Fatal case of sepsis caused by a non-haemolytic strain of Streptococcus pyogenes. J Clin Pathol. 2007;60(9):1057. doi: 10.1136/jcp.2007.048793. [PubMed: 17513506].

45. Sonksen UW, Ekelund K, Bruun BG. Case of bacteraemic cellulitis by a non-haemolytic strain of Streptococcus pyogenes. Scand J Infect Dis. 2007;39(3):262-4. doi: 10.1080/00365540600868362. [PubMed: 17366061].

46. Karki S, Leder K, Cheng AC. Should we continue to isolate patients with vancomycin-resistant enterococci in hospitals?. Med J Aust. 2015;202(5):234-6. [PubMed: 25758685].

47. Kaiser L, Emonet S, Huttner A, Vetter P, Toutous Trellu L, Uriel Valladares Bickel P, et al. [Infections disease update: 2014 is viral]. Rev Med Suisse. 2015;11(456-457):72-7. [PubMed: 25799655].

48. Tendolkar PM, Baghdayan AS, Shankar N. Pathogenic enterococci: new developments in the 21st century. Cell Mol Life Sci. 2003;60(12):2622-36. doi: 10.1007/s00018-003-3138-0. [PubMed: 14685687].

49. Mohammadi F, Tabaraie B, Sadeghifard N, Ghafoorian S, Maleki A Davoodian E, et al. Evaluation of drug resistance frequency among Entrococci faecium and E. faecalis strains and detection of VanA/B genes in vancomycin resistance isolated by PCR method in ilam and kermanshah hospitals. Iran J Med Microbiol. 2011;5(1):14-8.

50. Babic M, Hujer AM, Bonomo RA. What's new in antibiotic resistance? Focus on beta-lactamases. Drug Resist Updat. 2006;9(3):142-56. doi: 10.1016/j.drup.2006.05.005. [PubMed:16899402].

51. Abdalla HI, Bhattacharya S, Khalaf Y. Is meaningful reporting of national IVF outcome data possible?. Hum Reprod. 2010;25(1):9-13. doi: 10.1093/humrep/dep357. [PubMed: 19819894].

52. Hoffmann H, Sturenburg E, Heesemann J, Roggenkamp A. Prevalence of extended-spectrum beta-lactamases in isolates of the Enterobacter cloacae complex from German hospitals. Clin Microbiol Infect. 2006;12(4):322-30. doi: 10.1111/j.1469-0691.2006.01360.x. [PubMed: 16524408].

53. Nikolic M, Arandjelovic M, Stankovic A, Krivokapic LJ. Bacterial contamination of mobile phones used in hospitals. Health Med. 2011;5(5):1254-9.

54. Vandenesch F, Lina G, Henry T. Staphylococcus aureus hemolysins, bicomponent leukocidins, and cytolytic peptides: a redundant arsenal of membrane-damaging virulence factors?. Front Cell Infect Microbiol. 2012;2:12. doi: 10.3389/fcimb.2012.00012. [PubMed: 22919604].

55. Chaibenjawong P, Foster SJ. Desiccation tolerance in Staphylococcus aureus. Arch Microbiol. 2011;193(2):125-35. doi:10.1007/s00203-0100653-x. [PubMed: 21088825].

56. Holmes JW, Williams MD. Methicillin-resistant staphylococcus aureus screening and eradication in the surgical intensive care unit: Is it worth it?. Am J Surg. 2010;200(6):827-30. doi: 10.1016/j.amjsurg.2010.08.003. [PubMed: 21146028] discussion 
830-1.

57. Alighardashi M, Aeini M, Naeinian F, Mohamadi H. The amount and type of microbial contamination on cell phones of medical staff in Shahid Beheshti Hospital, Hamadan, Iran. Health System Res. 2011;7(6):1-9.

58. Morioka I, Tabuchi Y, Takahashi Y, Oda Y, Nakai M, Yanase A, et al. [Bacterial contamination of mobile phones shared in hospital wards and the consciousness and behavior of nurses about biological cleanliness]. Nihon Eiseigaku Zasshi. 2011;66(1):115-21. [PubMed: 21358142].

59. Zakai S, Mashat A, Abumohssin A, Samarkandi A, Almaghrabi B, Barradah $\mathrm{H}$, et al. Bacterial contamination of cell phones of medical students at King Abdulaziz University, Jeddah, Saudi Arabia.J Microscopy Ultrastructure. 2016;4(3):143-6.

60. Braddy CM, Blair JE. Colonization of personal digital assistants used in a health care setting. Am J Infect Control. 2005;33(4):230-2. doi: 10.1016/j.ajic.2005.03.003. [PubMed: 15877018].

61. Beer D, Vandermeer B, Brosnikoff C, Shokoples S, Rennie R, Forgie S. Bacterial contamination of health care workers' pagers and the efficacy of various disinfecting agents. Pediatr Infect Dis J. 2006;25(11):1074-5. doi: 10.1097/01.inf.0000242649.27400.94. [PubMed: 17072134].

62. Goldblatt JG, Krief I, Klonsky T, Haller D, Milloul V, Sixsmith DM, et al. Use of cellular telephones and transmission of pathogens by medical staff in New York and Israel. Infect Control Hosp Epidemiol 2007;28(4):500-3. doi: 10.1086/513446. [PubMed: 17385162].

63. Jayalakshmi J, Appalaraju B, Usha S. Cellphones as reservoirs of nosocomial pathogens. J Assoc Physicians India. 2008;56:388-9. [PubMed: 18700649].

64. Hassoun A, Vellozzi EM, Smith MA. Colonization of personal digital assistants carried by healthcare professionals. Infect Control Hosp Epidemiol. 2004;25(11):1000-1. doi: 10.1086/502334. [PubMed: 15566038].

65. Singh D, Kaur H, Gardner WG, Treen LB. Bacterial contamination of hospital pagers. Infect Control Hosp Epidemiol. 2002;23(5):274-6. doi: 10.1086/502048. [PubMed: 12026153].

66. Barari SR, Pornasrollah M, Rajabnia R, Salar N, Bijani A, Mirzapour M Comparison of the microbial colonization of mobile phone between health care personnel and non-care personnel of Babol university of medical science hospitals. JBUMS. 2014;16(5):67-71.

67. Borer A, Gilad J, Smolyakov R, Eskira S, Peled N, Porat N, et al. Cell phones and Acinetobacter transmission. Emerg Infect Dis. 2005;11(7):1160-1. doi: 10.3201/eid1107.050221. [PubMed: 16032803].

68. Brady RR, Verran J, Damani NN, Gibb AP. Review of mobile communication devices as potential reservoirs of nosocomial pathogens.J Hosp Infect. 2009;71(4):295-300. doi: 10.1016/j.jhin.2008.12.009. [PubMed: 19168261]. 